\title{
Populational fluctuation of lace bug in cassava
}

\section{Flutuação populacional do percevejo-de-renda em cultivares de mandioca}

\author{
Patrícia Paula Bellon * , Harley Nonato de Oliveira², Elisângela de Souza Loureiro², \\ Danilo Renato Santiago Santana ${ }^{1}$, Auro Akio Otsubo ${ }^{2}$, Thiago Alexandre Mota'
}

\begin{abstract}
Vatiga illudens is a pest of economic importance for the cultivation of cassava. Knowing the time of incidence of this insect in combination with environmental factors enables control strategies. The objective of this study was to determine the population dynamics of $V$. illudens in cassava cultivars and the correlation of these insects for climatic factors in Dourados, Mato Grosso do Sul. Four cultivars of cassava were evaluated: Kiriris, N-25, IAC 90 and Fécula Branca. Population assessment of the lace bug was conducted over 18 months observing 2 crop cycles. Fortnightly, they were randomly sampled four central plants of each plot and five leaves from the middle third of each plant, quantifying the number of nymphs and adults per leaf. Twenty months after planting cassava, two central rows of each plot were harvested and measured productivity in $\mathrm{kg} \mathrm{ha}^{-1}$. The experimental design was randomized blocks with four treatments and two replications. The peak population of nymphs and adults for the first crop cycle occurred during the months from March to May. For the second cycle, these population indices happened in the months from January to April. Cultivar Kiriris showed the highest mean number of nymphs and adults per leaf cassava and cultivar IAC 90, the lowest number of insects. There was a negative correlation between the population of adult insects and root yield. The maximum, mean and minimum temperatures affected the population of nymphs $V$. illudens. These results are fundamental to define management strategies for control of lace bug.
\end{abstract}

KEYWORDS: Vatiga illudens; Manihot esculenta; integrated pest management.
RESUMO: Vatiga illudens é uma praga de importância econômica para a cultura da mandioca. Conhecer a época de incidência desse inseto em associação com fatores ambientais possibilita estratégias de controle. $\mathrm{O}$ objetivo deste trabalho foi determinar a flutuação populacional de $V$. illudens em cultivares de mandioca e verificar a correlação desses insetos com os fatores climáticos em Dourados, Mato Grosso do Sul. Foram avaliadas quatro cultivares de mandioca: Kiriris, N-25, IAC 90 e Fécula Branca. A avaliação populacional do percevejo-de-renda foi realizada durante 18 meses, observando 2 ciclos da cultura. Quinzenalmente, foram amostradas aleatoriamente quatro plantas centrais de cada parcela e cinco folhas do terço médio de cada planta, quantificando o número de ninfas e adultos por folha. Vinte meses após o plantio, foram colhidas duas fileiras centrais de mandioca de cada parcela e mensurada a produtividade em $\mathrm{kg} \mathrm{ha}^{-1}$. O delineamento experimental foi em blocos casualizados com quatro tratamentos e duas repetiçóes. O pico populacional das ninfas e adultos para o primeiro ciclo da cultura ocorreu nos meses de março a maio. Para o segundo ciclo, esses índices populacionais aconteceram nos meses de janeiro a abril. O cultivar Kiriris apresentou maior número médio de ninfas e de adultos por folha de mandioca e o cultivar IAC 90, o menor número de insetos. Houve correlação negativa entre a população de insetos adultos e a produtividade de raízes. As temperaturas máximas, médias e mínimas afetaram a população de ninfas de $V$. illudens. Esses resultados são fundamentais para definir estratégias de manejo para controle do percevejo-de-renda.

PALAVRAS-CHAVE: Vatiga illudens; Manihot esculenta; manejo integrado de pragas.

'Programa de Pós-graduação em Entomologia e Conservação da Biodiversidade, Faculdade de Ciências Biológicas e Ambientais, Universidade Federal da Grande Dourados (UFGD) - Dourados (MS), Brazil.

${ }^{2}$ Embrapa Agropecuária Oeste - Dourados (MS), Brazil.

${ }^{3}$ Universidade Federal de Mato Grosso do Sul (UFMS) - Chapadão do Sul (MS), Brazil.

*Corresponding author: phatriciabellon@yahoo.com.br

Received on: 7/02/2015. Accepted on: 3/24/2017 


\section{INTRODUCTION}

Brazil, the center of origin of cassava (Manihot esculenta Crantz) (OLSEN, 2004), is the second largest producer of it in the world (IBGE, 2014). It has a high socioeconomic importance, as cassava is the main source of carbohydrates and subsistence for the most deprived populations, besides being an important basis for animal feed and starch production (SOUZA; FARIA, 2006).

The state of Mato Grosso do Sul is responsible for $3.2 \%$ of the national production of cassava, producing 680,000 tons of roots per year (IBGE, 2014). Despite its low national participation, the sector has shown great growth potential due to the region's edaphoclimatic conditions, the implantation of starch processing industries and the high consumption of table cassava, constituting, therefore, an important economic alternative for the producers (OTSUBO; PEZARICO, 2002).

Cultivation of cassava is affected by the occurrence of pests and diseases that can significantly compromise the final crop yield (EL-SHARKAWY, 2004). It is estimated that about 200 arthropod species causes damage to cassava in the Americas, but there are gaps in the knowledge of production losses, population levels of control and economic damage (BELLOTTI et al., 1999).

Among the pests, we can highlight the Vatiga illudens (Drake, 1922) (Hemiptera: Tingidae), which in recent years has shown visible population growth in cassava plantations, mainly in the states of Paraná (ALVES et al., 2012) and Mato Grosso do Sul (BELLON et al., 2012). Nymphs and adults feed on the protoplast of the foliar parenchyma cells, causing photosynthesis reduction, lower leaf fall, and severe infestations causing complete plant defoliation (BELLOTTI, 2002; LOZANO et al., 1983), reducing crop productivity by up to 55\% (FIALHO et al., 2009).

Currently, there are difficulties in the control of the lace bug, since there are no chemical or biological products registered for this insect (AGROFIT, 2003), nor other measures with control efficiency (CEBALHOS et al., 2004).

Monitoring is the main component of Integrated Pest Management, which is fundamental in the implementation of strategies that make up integrated production by promoting the rationalization of insect control through the monitoring of variation in the number of individuals over time. Although it is an alternative in the search for control strategies, few studies have been carried out in order to know the population behavior of the lace bug in cassava (MARTINAZZO et al., 2007). For this reason, the aim of this study was to determine the population fluctuation of $V$. illudens in cassava cultivars and verify the correlation of these insects with the climatic factors in the municipality of Dourados, Mato Grosso do Sul.

\section{MATERIAL AND METHODS}

The experiment was carried out in a sample area of 201.6 $\mathrm{m}^{2}$ in the municipality of Dourados, Mato Grosso do Sul. The climate in the region, according to the Köppen classification, is of the Cwa (wet mesothermal) type, with rainy summer and dry winter, with an average annual precipitation of $1,500 \mathrm{~mm}$ and an average annual temperature of $22^{\circ} \mathrm{C}$. The daily records of maximum, average and minimum temperatures $\left({ }^{\circ} \mathrm{C}\right)$, precipitation $(\mathrm{mm})$ and relative humidity (\%) in the period corresponding to this study were obtained through the database of a meteorological station of Embrapa Agropecuária Oeste, located in Dourados, Mato Grosso do Sul (Fig. 1).

Four cassava cultivars were evaluated: Kiriris, N-25, IAC 90 and Fécula Branca. Planting was done in October 2010. Sampling of the lace bug was begun in the first half of January 2011, when the plants were 3 months old and 17 leaves per plant were developed. The experimental design was a randomized block design consisting of four treatments (cultivars) and two replicates (blocks). Each plot, with a total area of $25.2 \mathrm{~m}^{2}$, was composed of 4 lines with 40 plants spaced $0.90 \mathrm{~m}$ between rows and $0.70 \mathrm{~m}$ between plants.

During the insect sampling period, no control method was used for $V$. illudens; however, the biological product Bac-Control WP ${ }^{\circ}$ (Bacillus thuringiensis) (500 g ha-1) was used in the crop to control the Erinniys ello caterpillars (Linnaeus, 1758) (Lepidoptera: Sphingidae) in the month of December 2010.

In the months of July (2011 and 2012) and August (2011), there were no samplings of the lace bug population, because the cassava plants lost their leaves during the winter period. In the first half of August 2011, pruning of cassava plants was also carried out, an usual practice used by the cassava producers from the state.

The population evaluation was carried out during the period of 18 months, from January 2011 to June 2012. Four plants were randomly sampled from each plot, and five leaves from the middle third of each plant were randomly sampled (MARTINAZZO et al., 2007), quantifying the number of lace bug nymphs and adults per leaf. Twenty months after planting, two central rows of cassava were harvested from each plot and yield was measured in $\mathrm{kg} \mathrm{ha}^{-1}$, based on the weighting of the roots of the harvested area.

The population fluctuation was analyzed and the data compiled through graphical analysis and simple linear correlation between the number of $V$. illudens nymphs and adults, cultivar productivity and climatic factors (maximum, average, minimum, pluviometric precipitation and relative humidity). The comparison between the cultivars and the sampled population was done through the Tukey's test at $5 \%$ probability. 


\section{RESULTS AND DISCUSSION}

The population fluctuation of $V$. illudens nymphs and adults varied in relation to the plants of the first cycle (first year of evaluation) and second cycle (second year of evaluation) (Figs. 2 and 3). In the first cycle, the population of nymphs had their population peak in the month of March and April and a new increase of the population in May (Fig. 2). For the second cycle, this population began to increase in November, reaching its population peaks in the months of December to February and again in April (Fig. 2).

Adult population behavior was similar to that observed for nymphs. In the first cycle, the increase of adult insects began in February with peak population in April and May (Fig. 3). In the second cycle, regarding the nymphs, this population also increased in the hot months of the year (November and December), with peaks from February to April, decreasing in the following months (Fig. 3).

Although there are still few studies that determine the population fluctuation of the lace bug, studies carried out in different locations with several cassava cultivars have shown that the population peaks of this insect-plague can occur between November and May (MARTINAZZO et al., 2007; OLIVEIRA, 1997), corroborating with the results of the present study.

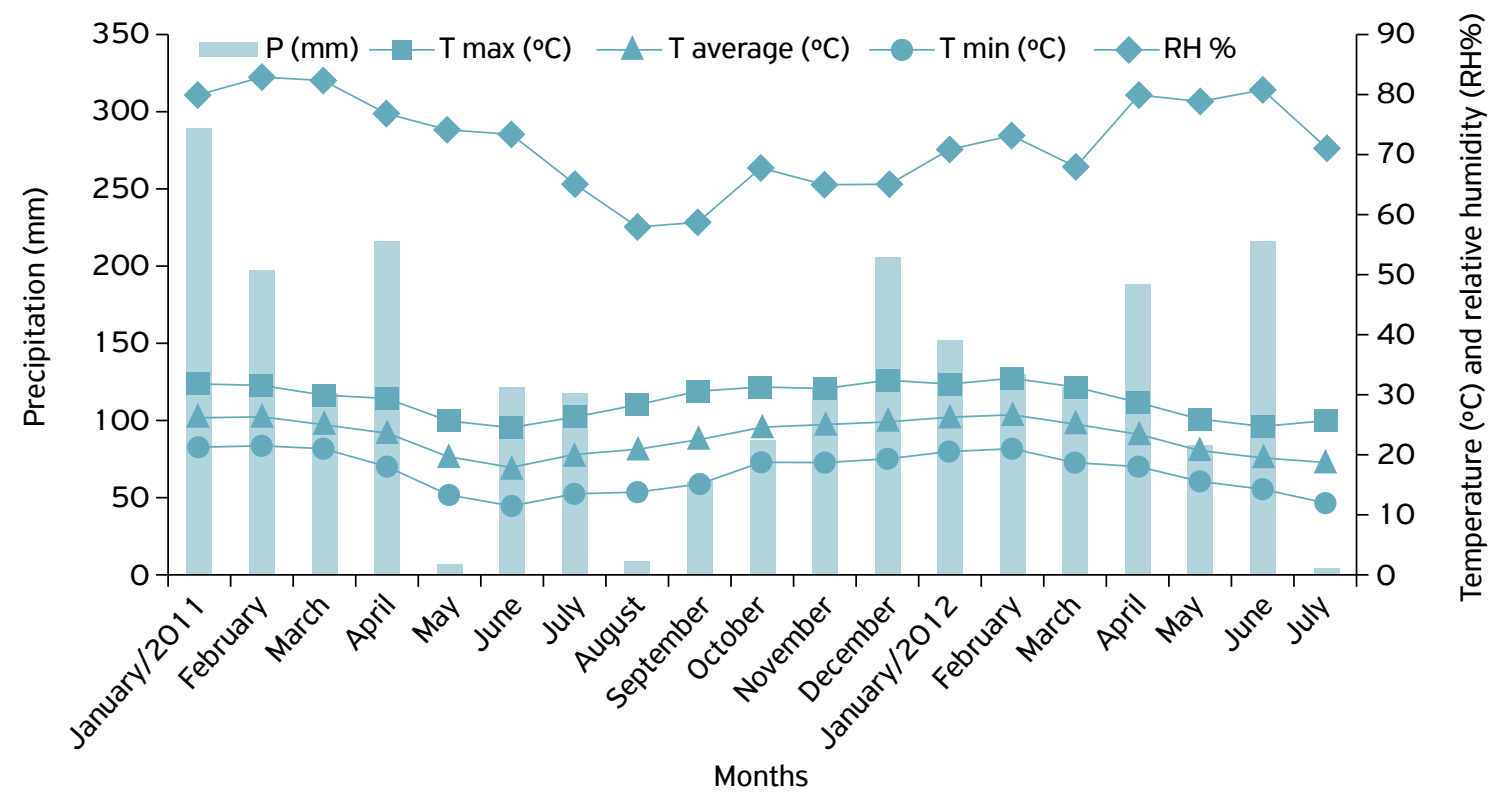

Figure 1. Precipitation (mm), maximum temperatures $\left(\mathrm{T}\right.$ max. $\left.{ }^{\circ} \mathrm{C}\right)$, minimum $\left(\mathrm{T} \mathrm{min} .{ }^{\circ} \mathrm{C}\right)$ and averages $\left(\mathrm{T}\right.$ average $\left.{ }^{\circ} \mathrm{C}\right)$ and relative humidity (RH\%) from January 2011 to June 2012, Mato Grosso do Sul.

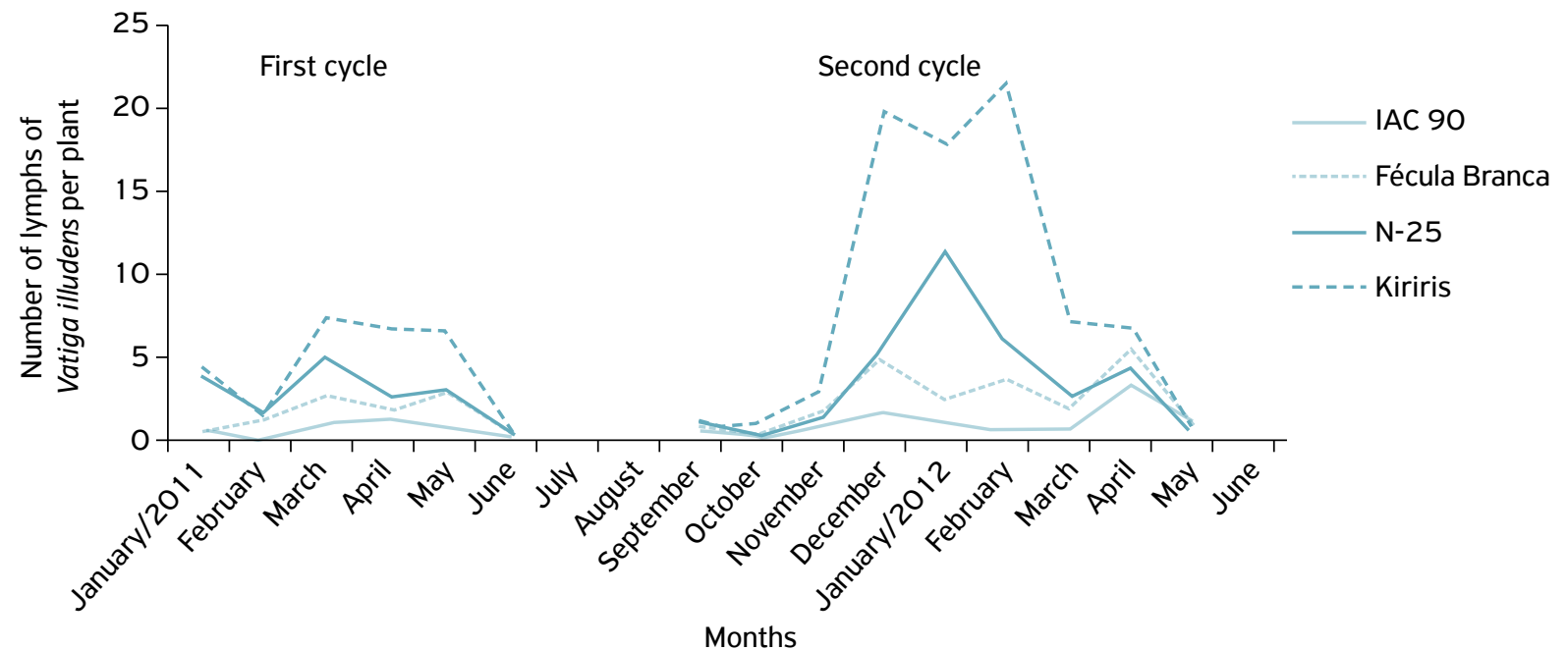

Figure 2. Mean population fluctuation of nymphs of Vatiga illudens (Hemiptera: Tingidae) in different cassava cultivars from January 2011 to June 2012, Dourados, Mato Grosso do Sul. 
The population decline (nymphs and adults) occurred in June (Figs. 2 and 3). This decrease and even absence of insects occur because the cassava plant loses its leaves and paralyzes its growth during the winter period, marking its winter rest, and, as temperatures increase in the spring and become favorable for the budding of the buds, the cycle of plant growth is restarted (FAGUNDES et al., 2010). Moreover, the behavior of the lace bug in this winter period is still unknown, not knowing if the insect enters diapause in the cultural remains of the area or if there is a migration to areas of refuge (MARTINAZZO et al., 2007).

The population increase of the lace bug nymphs and adults was higher in the second crop cycle (Figs. 2 and 3). MARTINAZZO et al. (2007), determining the population fluctuation of $V$. manihotae, also verified a higher incidence of these insects for the second cassava cycle. According to these authors, the increase in the number of insects in this cycle of the crop may be related to the formation of a more intense foliar mass in the regrowth of the plant, with greater food availability, allowing the insect to complete a larger number of generations in that period and consequently increase its population.

In relation to the cultivars, Kiriris presented a higher number of nymphs $(3.61 \pm 0.32)$ and adults $(0.73 \pm 0.03)$ per leaf, differing statistically from the other cultivars evaluated (Table 1). N-25 and Fécula Branca did not differ among themselves in the number of nymphs $(1.69 \pm 0.14$ and $1.05 \pm 0.06)$ and adults $(0.35 \pm 0.04$ and $0.27 \pm 0.01)$, respectively; and IAC 90 presented the lowest numbers of insects ( $0.41 \pm 0.04$ nymphs and $0.07 \pm 0.01$ adults), but this cultivar did not differ from the Fécula Branca for the average number of nymphs (Table 1 ).

A factor that can also be related to these differences of V. illudens attacks among the cultivars are the contents of cyanogenic compounds in the plants (COSENZA et al., 1981), a fact verified by VIEIRA et al. (2011) observing that the higher the hydrocyanic acid content in the cassava roots, the lower the incidence of $V$. illudens nymphs and adults. However, in the present work, the cyanogenic contents of the studied materials were not known.

The correlation coefficient between adult insects and root productivity was significant and negative $(-0.74)$ (Table 2), demonstrating that in the evaluation period the number of lace bug adults was related to the decrease of root productivity. Similar results were obtained by Fialho et al. (2009) who found a negative correlation for $V$. illudens nymphs and adults with root and shoot productivity of cassava in three years of evaluation.

Table 1. Mean number ( \pm standard error) of nymphs and adults of Vatiga illudens (Hemiptera: Tingidae) per cassava plant from January 2011 to June 2012, in Dourados, Mato Grosso do Sul.

\begin{tabular}{lcc} 
Cultivars & Number of nymphs & Number of adults \\
\hline Kiriris & $3.61 \pm 0.32 \mathrm{a}^{*}$ & $0.73 \pm 0.03 \mathrm{a}$ \\
\hline $\mathrm{N}-25$ & $1.69 \pm 0.14 \mathrm{~b}$ & $0.35 \pm 0.04 \mathrm{~b}$ \\
\hline Fécula Branca & $1.05 \pm 0.06 \mathrm{bc}$ & $0.27 \pm 0.01 \mathrm{~b}$ \\
\hline IAC 90 & $0.41 \pm 0.04 \mathrm{c}$ & $0.07 \pm 0.01 \mathrm{c}$ \\
\hline CV (\%) & 30.36 & 22.43
\end{tabular}

*Means followed by the same letter in the column are not different at $5 \%$ of probability, by Tukey's test.

Table 2. Correlation coefficient ( $R$ ) between root productivity (kg ha-1) and population of nymphs and adults of Vatiga illudens (Hemiptera: Tingidae), present in cassava cultivars from January 2011 to June 2012, Dourados, Mato Grosso do Sul.

\begin{tabular}{lcc}
\multicolumn{3}{c}{ Correlation coefficient (R) } \\
Productivity $\left(\mathrm{kg} \mathrm{ha}^{-1}\right)$ & Nymphs & Adults \\
\cline { 2 - 3 } & $-0.64^{\mathrm{ns}}$ & $-0.74^{*}$ \\
\hline
\end{tabular}

* Significant correlational level of $p<0.05$.

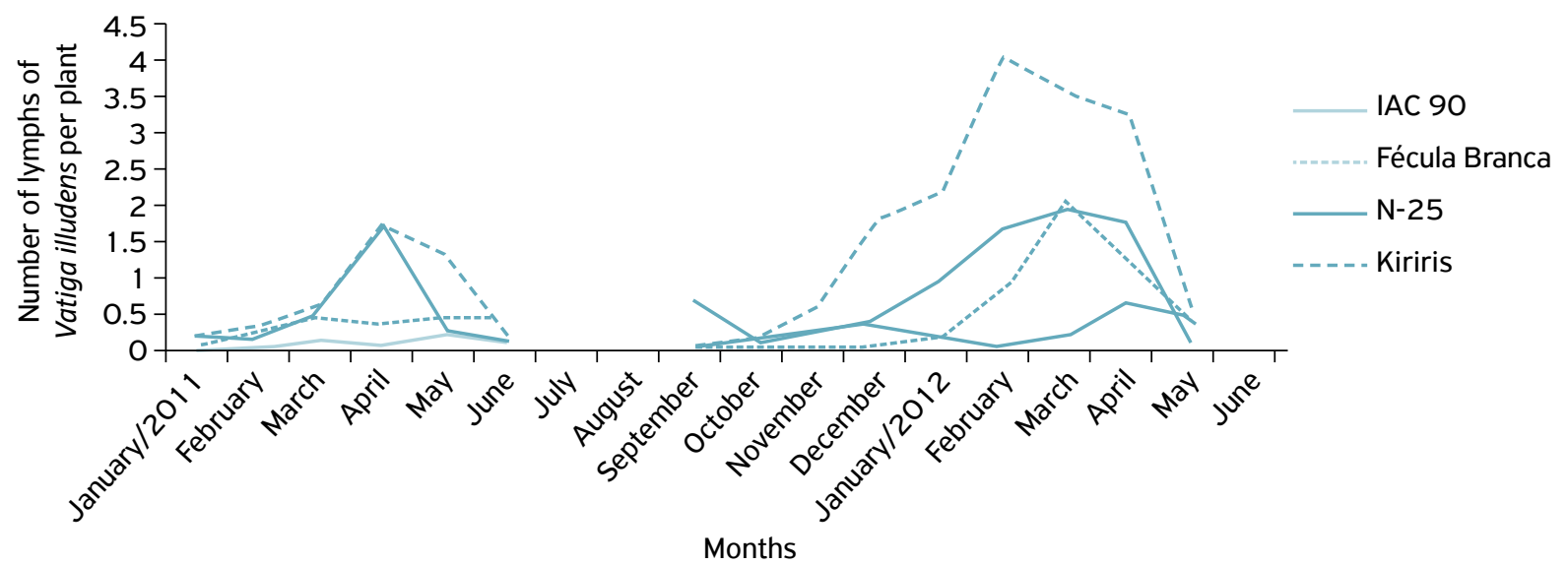

Figure 3. Mean population fluctuation of adults of Vatiga illudens (Hemiptera: Tingidae) in different cassava cultivars from January 2011 to June 2012, Dourados, Mato Grosso do Sul. 
For the nymph population, no significant correlation was observed in root productivity (-0.64) (Table 2). However, this correlation was negative, also evidencing a tendency of productivity decrease due to the presence of these insects.

The decrease in productivity due to the number of lace bug adults can be related to the damage that the insect causes the leaves through the suction, causing the plant to accumulate less photoassimilates due to the decrease of the photosynthetically active leaf area and to spend energy in the recomposition of the leaves that fell due to the insect attack (FARIAS, 1987; FIALHO et al., 2009).

Regarding climatic factors, it was observed that the mean, minimum and maximum temperatures positively affected only the nymph population, constituting an important factor for the occurrence of this insect (Table 3). The correlation coefficient obtained between these climatic factors and the nymphs showed that, as temperatures increased, there was also an increase in the number of $V$. illudens nymphs sampled (Figs. 1 and 2).

Precipitation did not correlate with the variation of the lace bug nymphs and adults population. The excess and scarcity of rainfall was not a limiting factor for the development of these insects. However, rainfall during the months of December (2011) to April (2012), with the high temperatures of these months (Fig. 1), contributed to the growth (nymphs and adults) sampled for this period (Figs. 2 and 3).

In the same way that the population fluctuation of the lace bug was not influenced by precipitation, there was also no effect of relative humidity on the incidence of this insect (Table 3 ).

The increase of the lace bug population and the insect attack occur mainly during the dry season, aggravating in periods with prolonged drought (BELLOTTI et al., 2002), a fact that was not observed in the present study. However, it should be noted that the two years of sampling (January 2011 to July 2012) were atypical for the pluvial regime for the Dourados region, presenting high rainfall in all months of the year, except in May and August (2011) and July (2012) (Table 1). This differentiation in the pluviometric regime may have influenced the number of nymphs and adults sampled during the evaluation period.
It is important to point out that research with a population fluctuation of a pest and its relation with climatic factors present different results from one region to another, that is, the factor that presents a significant correlation in one region may not be relevant in another region, showing that the fluctuation population is specific to each site evaluated (PORTELA et al., 2010).

Therefore, further studies on the occurrence and population fluctuation of $V$. illudens in the Dourados region and in several regions of Brazil are required, as well as studies involving levels of economic damage and resistance of cultivars that minimize or disfavor the attack of these insects- plague. This information will be fundamental for defining control strategies for the lace bug.

\section{CONCLUSIONS}

The population peak of $V$. illudens nymphs and adults for the first cycle of the crop occurred in the months of March to May and, in the second cycle, these population indices happened in the months of January to April. The Kiriris cultivar showed a higher average number of nymphs and adults per cassava leaf and the cultivar IAC-90, the lowest number of insects. The number of lace bug adult insects negatively influenced the root productivity. Under the conditions tested, maximum, medium and minimum temperatures positively affected the population of $V$. illudens nymphs, and precipitation and relative humidity did not influence the incidence of this insect.

\section{ACKNOWLEDGEMENTS}

The Fundação de Apoio ao Desenvolvimento do Ensino, Ciência e Tecnologia do Estado de Mato Grosso do Sul (FUNDECT - Foundation for Support to the Development of Education, Science and Technology of the State of Mato Grosso do Sul) for granting a doctorate scholarship and Embrapa Agropecuária Oeste for the availability of the sample area and laboratories.

Table 3. Coefficient of correlation ( $R$ ) between climatic factors and population of nymphs and adults of Vatiga illudens (Hemiptera: Tingidae), present in the cassava crop from January 2011 to June 2012, Dourados, Mato Grosso do Sul.

\begin{tabular}{|lccccc}
\hline $\begin{array}{c}\text { Coefficient of } \\
\text { correlation }(\mathrm{R})\end{array}$ & $\begin{array}{c}\text { Maximum } \\
\text { temperature }\left({ }^{\circ} \mathrm{C}\right)\end{array}$ & $\begin{array}{c}\text { Average } \\
\text { temperature }\left({ }^{\circ} \mathrm{C}\right)\end{array}$ & $\begin{array}{c}\text { Minimum } \\
\text { temperature }\left({ }^{\circ} \mathrm{C}\right)\end{array}$ & $\begin{array}{c}\text { Precipitation } \\
(\mathbf{m m})\end{array}$ & $\begin{array}{c}\text { Relative humidity } \\
(\mathrm{RH} \%)\end{array}$ \\
\hline Nymphs & $0.5823^{* *}$ & $0.6093^{* *}$ & $0.5977^{* *}$ & $0.302^{\mathrm{ns}}$ & $0.0875^{\mathrm{ns}}$ \\
\hline Adults & $0.3778^{\mathrm{ns}}$ & $0.1732^{\mathrm{ns}}$ & $0.3928^{\mathrm{ns}}$ & $0.1732^{\mathrm{ns}}$ & $0.1444^{\mathrm{ns}}$ \\
\hline
\end{tabular}

**Significant correlation at level of $p<0.01$. 
AGROFIT. Sistema de Agrotóxicos Fitossanitários. 2003. Available from: <http://extranet.agricultura.gov.br/agrofit_cons/principal_ agrofit_cons>. Accessed on: May 16, 2014.

ALVES, L.F.A.; BELLON, P.P.; RHEINHEIMER, A.R.; PIETROWSKI, V. First record of Beauveria bassiana (Hyphomycetes: Moniliales) on adults of cassava lace bug Vatiga manihotae (Drake) (Hemiptera: Tingidae) in Brazil. Arquivos do Instituto Biológico, São Paulo, v.79, n.2, p. 309-311, 2012.

BELLON, P.P.; WENGRAT, A.P.G.S.; KASSAB, S.O.; PIETROWSKI, V.; LOUREIRO, E.D. Occurrence of lace bug Vatiga illudens and Vatiga manihotae (Hemiptera: Tingidae) in Mato Grosso do Sul, midwestern Brazil. Anais da Academia Brasileira de Ciências, Rio de Janeiro, v.84, n.3, p.703-705, 2012.

BELLOTTI, A.C. Arthropod pests. In: HILLOCKS, R.J.; THRESH, J.M.; BELLOTTI, A.C. (Eds.). Cassava: biology, production and utilization. Oxon: CAB International, 2002. Chap.11. p.209-236.

BELLOTTI, A.C.; ARIAS, V.B.; VARGAS, H.O.; REYES, Q.J.A.; GUERREIRO, J.M. Insectos y ácaros dañinos a la yuca y su control. In: OSPINA, P.; CEBALLOS, H.; ALVAREZ, E.; BELLOTTI, A.C.; CALVERT, L.A.; ARIAS, V.B.; CADAVID, L.F.; PINEDA, L.; BENJAMÍN,L.R.; GERMÁN, A.; CUERVO, M.I. (Eds.). La yuca en el tercer milenio: sistemas de producción, procesamiento, utilización y comercialización. Palmira: CIAT, 2002. Chap.10. p.160-203.

BELLOTTI, A.C.; SMITH, L.; LAPOINTE, S.L. Recent advances in cassava pest management. Annual Review of Entomology, Palo Alto, v.44, p.343-370, 1999.

CEBALHOS, H.; IGLESIAS, C.A.; PÉREZ, J.C.; DIXON, A.G.O. Cassava breeding: opportunities and challenges. Plant Molecular Biology, Zurich, v.56, n.4, p.503-516, 2004.

COSENZA, G.W.; PERIM, S.; COSTAL, I.R.S. Resistência de variedades de mandioca ao percevejo-de-renda, Vatiga illudens (Drake, 1922). Planaltina: Embrapa Cerrados, 1981. 6p. (Pesquisa em Andamento).

EL-SHARKAWY, M.A. Cassava biology and physiology. Plant Molecular Biology, Zurich, v.56, n.4, p.481-501, 2004.

FAGUNDES, L.K.; STRECK, N.A.; ROSA, H.T.; WALTER, L.C.; ZANON, A.J.; LOPES, S.J. Desenvolvimento, crescimento e produtividade de mandioca em diferentes datas de plantio em região subtropical. Ciência Rural, Santa Maria, v.40, n.12, p.2460-2466, 2010.

FARIAS, A.R.N. Biologia de Vatiga illudens (Drake, 1922) (Hemiptera: Tingidae) em laboratório. Revista Brasileira de Mandioca, Cruz das Almas, v.6, n. 1, p.17-19, 1987.
FIALHO, J. de F.; VIEIRA, E.A.; PAULA-MORAES, S.V. de; SILVA, M.S.; JUNQUEIRA, N.T.V. Danos causados por percevejo-derenda na produção de parte aérea e raízes de mandioca. Scientia Agraria,Curitiba, v.10, n.2, p.151-155, 2009.

INSTITUTO BRASILEIRO DE GEOGRAFIA E ESTATÍSTICA (IBGE). Levantamento sistemático da produção agrícola. Available from: <http://www.sidra.ibge.gov.br/bda/prevsaf/default.asp?t=2\& $\mathrm{z}=\mathrm{t} \& \mathrm{o}=26 \& \mathrm{u} 1=1 \& \mathrm{u} 2=1 \& \mathrm{u} 3=1 \& \mathrm{u} 4=1>$. Accessed on: May $16,2014$.

LOZANO, J.C.; BELLOTTI, A.C.; REYES, J.A.; HOWELER, R.; LEIHNER, D.; DOLL, J. Problemas no cultivo da mandioca. Brasília: Embrapter/CIAT, 1983. 207p.

MARTINAZZO, T.; KRAEMER, B.; CASTOLDI, G.; FIORESE, S.; LOHMANN, T.R.; PIETROWSKI, V. Flutuação populacional do percevejo de renda na cultura da mandioca na região oeste do Paraná. Raízes e Amidos Tropicais, Botucatu, v.3, 2007.

OLIVEIRA, M.A.S.; FIALHO, J.de F.; ALVES, R.T.; OLIVEIRA, J.N.S.; GOMES, A.C. Comportamento populacional do percevejo-de-renda Vatiga illudens (Drake, 1922) (Hemiptera: Tingidae) na cultura da mandioca (Manihot esculenta, Crantz) no Distrito Federal. Revista Brasileira de Mandioca, Botucatu, v.17, n.1/2, p.25-31, 1997.

OLSEN, K.M. SNPs, SSRs and inferences on cassava's origin. Plant Molecular Biology, Zurich, v.56, n.4, p.517-526, 2004.

OTSUBO, A.A.; PEZARICO, C.R.A. Cultura da mandioca em Mato Grosso do Sul. In: OTSUBO, A.A.; MERCANTE, F.M.; MARTINS, C.S. de S.(Eds.). Aspectos do Cultivo da Mandioca em Mato Grosso do Sul. Dourados/Campo Grande: Embrapa Agropecuária Oeste/ UNIDERP, 2002. Chap.2, p.31-48.

PORTELA, G.L.F.; PÁDUA, L.E. de M.; BRANCO, R.T.P.C.; BARBOSA, O. de A.; SILVA, P.R.R. Flutuação populacional de Diatraea saccharalis (Fabricius, 1794) (Lepidoptera - Crambidae) em cana-de-açúcar nomunicípio de União-PI. Revista Brasileira de Ciências Agrárias, Recife, v.5, n.3, p.303-307, 2010.

SOUZA, L. da S.; FARIA, A.R.N. Aspectos socioeconômicos e agronômicos da mandioca. Cruz das Almas: Embrapa Mandioca e Fruticultura Tropical, 2006. 817p.

VIEIRA, E.A.; FIALHO, J. de F.; FALEIRO, F.G.; BELLON, G.; FONSECA, K.G.; CARVALHO, L.J.C.B.; SILVA, M.S.; PAULA-MORAES, S.V.; OLIVEIRA, C.M.; DENKE, M.L. Characterization of sweet cassava accessions based on molecular, quantitative and qualitative data. Crop Breeding and Applied Biotechnology, Viçosa, v. 11 , n.3, p.232-240, 2011. 